\title{
Population Dynamics and Management of Two-barred Seabream Acanthopagrus bifasciatus in the Red Sea, Egypt
}

\author{
Samia Mohsen El-Mahdy ${ }^{1,}$, , Sahar Fahmy Mehanna ${ }^{1}$, Usama Mohammed Mahmoud², \\ Fahmy Ibrahim El-Gammal ${ }^{1}$ \\ ${ }^{1}$ Fish Population Dynamics Lab, Fisheries Division, National Institute of Oceanography and Fisheries, Alexandria, Egypt \\ ${ }^{2}$ Zoology Department, Faculty of Science, Assiut University, Assiut, Egypt
}

Email address:

samia_mohsen2004@yahoo.com (S. M. El-Mahdy)

${ }^{*}$ Corresponding author

\section{To cite this article:}

Samia Mohsen El-Mahdy, Sahar Fahmy Mehanna, Usama Mohammed Mahmoud, Fahmy Ibrahim El-Gammal. Population Dynamics and Management of Two-barred Seabream Acanthopagrus Bifasciatus in the Red Sea, Egypt. International Journal of Ecotoxicology and Ecobiology. Vol. 4, No. 4, 2019, pp. 80-87. doi: 10.11648/j.ijee.20190404.11

Received: August 1, 2019; Accepted: October 25, 2019; Published: October 31, 2019

\begin{abstract}
The present study is the first study on the population dynamics and management of the Acanthopagrus bifasciatus in the Egyptian sector of Red Sea. A total of 729 specimens were monthly collected from the Egyptian Red Sea during January 2015 to December 2015. Results showed that, the longevity of A. bifasciatus is 9 years in the Egyptian Red Sea and age group three was the most frequent one for combined sexes forming up to $26.61 \%$ of the total catch. The age group one was absent in the collected samples and the highest growth in length was observed at the end of the second year of life $(24.6 \mathrm{~cm})$ after which the annual increment decreases gradually with increase in age. The growth in weight was isometric. The length at first capture was $25.31 \mathrm{~cm}$ with corresponding age 2.22 year. The total, natural and fishing mortality were estimated as $1.99,0.46$ and 1.53 $\mathrm{yr}^{-1}$, respectively. The exploitation ratio E was estimated at 0.77 indicating a high level of exploitation. The yield per recruit analysis showed that the present level of fishing mortality is much higher than that gives the maximum yield per recruit by about $48 \%$ and the reduction of current level of fishing mortality coefficient from 1.53 to $0.8 / \mathrm{y}$ will be associated with an increase in the yield per recruit from 242.71 to $250.56 \mathrm{~g}(\approx 3 \%)$.
\end{abstract}

Keywords: Population Dynamics, Management, Acanthopagrus bifasciatus, Egyptian Red Sea

\section{Introduction}

Acanthopagrus bifasciatus is member of family Sparidae which represent the most important fish families in the Red sea. It is distributed in the Western Indian Ocean from the Red Sea and Arabian Gulf to Natal in South Africa. It is found in association with reefs in shallow coastal waters (2$20 \mathrm{~m}$ depth) and estuaries and bays [41]. A. bifasciatus occurs in small schools [24] and is exploited with a variety of gears including handlines and traps [41].

Fisheries management relies on understanding the fish population dynamics while determining the biological parameters including size at maturity, duration of the spawning season, as well as growth and mortality estimates [44].

The estimation of length-weight relationship and other population parameters is of great importance in the field of fish biology, stock assessment, population dynamics and fisheries management [18, 25, 28, 19].

Population dynamics are the processes responsible for changes in abundance or biomass of a population through time and are a subset of possible population parameters. Estimates of population dynamics can indicate how a population arrived at its current state and how it may change in the future [38]. These estimates consequently were used to fisheries management advice for reviewing different fishing options [22].

Although, Acanthopagrus bifasciatus is very important to the Egyptian economy, no studies were undertaken to assess its stock and to estimate its population parameters in the Egyptian waters. So, the present study was carried out to propose a future plan based on accurate scientific information 
to conserve $A$. bifasciatus stock in the Egyptian Red Sea.

\section{Material and Methods}

\subsection{Specimens' Collection}

In the present study, 442 males (17 - 56 cm in total length) and 287 females $(18-57 \mathrm{~cm}$ in total length) of $A$. bifasciatus were collected randomly from the southern Red Sea, Egypt during the period from January to December 2015. The total length was measured to the nearest centimeter and the body weight (W) was recorded to the nearest gram.

\subsection{Age Determination}

For age determination, the scales of $A$. bifasciatus were prepared and examined. Scales were taken from the area below the lateral line at a level behind the pectoral fin on the left side of the fish. The relationship between the scale radius (S) and the total length (TL) was used to estimate the necessary correction factor for back calculation. On the bases of scatter diagrams, such a relationship represented by the following equation: $\mathrm{TL}=\mathrm{a}+\mathrm{bS}$

Where "a" and "b" are constants estimated by the least square method.

\subsection{Length-weight Relationship}

Total length (TL)-weight (W) relationship was determined according to Hile [20] and Le Cren [23] as the following equation: $\mathrm{W}=\mathrm{a} \mathrm{TL}{ }^{\mathrm{b}}$

Where $\mathrm{a} \& \mathrm{~b}$ are constants, whose values are estimated by the least square method.

\subsection{Theoretical Growth}

The von Bertalanffy growth model was applied to describe the theoretical growth of $A$. bifasciatus. The constants of the von Bertalanffy model ( $\mathrm{L} \infty$ and $\mathrm{K}$ ) were estimated by using Ford [12] - Walford [45] plot.

$$
\mathrm{Y} / \mathrm{R}=\mathrm{Fe}^{-\mathrm{M}(\mathrm{Tc}-\mathrm{Tr})} \mathrm{W} \infty *\left[(1 / \mathrm{Z})-(3 \mathrm{~S} /(\mathrm{Z}+\mathrm{k}))+\left(3 \mathrm{~S}^{2} /(\mathrm{Z}+2 \mathrm{k})-\mathrm{S}^{3} /(\mathrm{Z}+3 \mathrm{k})\right]\right.
$$

Where $\mathrm{S}=\mathrm{e}^{-\mathrm{k}(\mathrm{Tc}-\mathrm{to})}$,

Moreover, Beverton and Holt's biomass per recruit (B/R) were also considered and hence the effect of mesh size was assessed under current growth characteristic of $A$. bifasciatus.

\section{Results}

\subsection{Age Determination}

The results showed that the maximum life span of the $A$. bifasciatus was 9 years for both males and females. The age of males, females and combined sexes of $A$. bifasciatus was composed of 8 age groups from age group II to age group IX. Age group III was the most dominant group for males and sexes combined forming $32.8 \%$ and $26.6 \%$ of the total samples respectively, while for females, the age group $\mathrm{V}$ was

\subsection{Length (Lc) and Age (Tc) at First Capture}

The length at first capture (the length at which $50 \%$ of the fish at that size are vulnerable to capture) was estimated by the analysis of catch curve using the method of Pauly [37] and the corresponding age at the first capture (Tc) was obtained by converting Lc to age using the von Bertalanffy growth equation as follows: $\mathrm{Tc}=-1 / \mathrm{K}$ $\operatorname{Ln}(1-\mathrm{Lc} / \mathrm{L} \infty)+\mathrm{t}_{0}$

\subsection{Mortality and Exploitation Rate Estimates}

\subsubsection{Total Mortality Coefficient (Z)}

Two different methods were used to estimate the total mortality coefficient; analysis of the cumulative catch curve method [21] and analysis of length converted catch curve [36].

\subsubsection{Natural Mortality Coefficient (M)}

The natural mortality coefficient was estimated by Rikhter and Efanov's Empirical model [39] and Pauly's Empirical Equation [35].

\subsubsection{Fishing Mortality Coefficient (F)}

The fishing mortality coefficient (F) was estimated by subtracting the value of natural mortality coefficient (M) from the value of total mortality coefficient $(Z)$ as the following: $\mathrm{F}=\mathrm{Z}-\mathrm{M}$

\subsubsection{Exploitation Rate (E)}

The exploitation rate (E) or expression of death from fishing during some specified period when all causes of death are affecting the population [11]. It was calculated according to the following relation: $E=F / Z[16,17]$

\subsection{Yield per Recruit (Y/R) Model}

The yield per recruit (Y/R) model of Beverton and Holt [3] was applied in the present work using the current growth parameters of $A$. bifasciatus. This model can be written according to Gulland [15] as:

the most frequent one forming $21.95 \%$ of the total collected samples (Figures 1 \& 2).

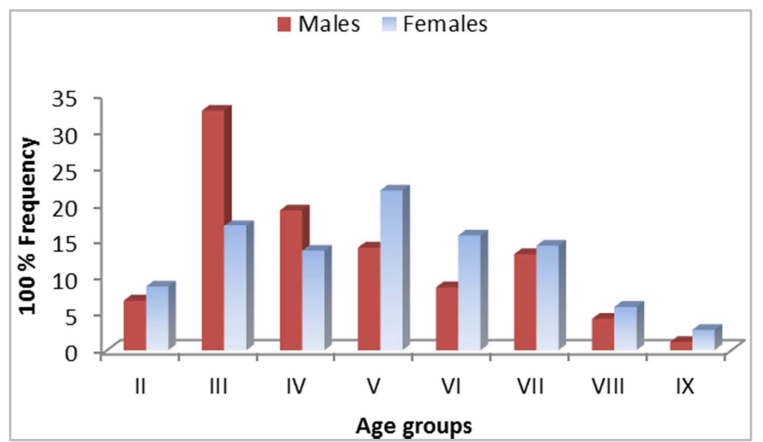

Figure 1. Age composition of Acanthopagrus bifasciatus (males and females) from Red Sea, Egypt. 


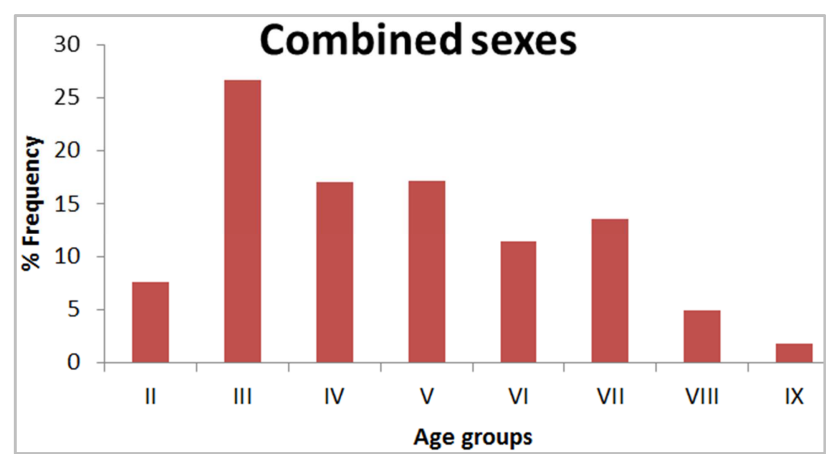

Figure 2. Age composition of Acanthopagrus bifasciatus (combined sexes) from Red Sea, Egypt.

\subsection{Back-calculations and Growth in Length}

The results showed that there is no difference between males and females in age and growth, so, the length by age was back-calculated for sexes combined. Since the relationship between total fish length and scale radius is linear and do not pass through the origin (Figure 3), the length of former ages was back ca

$$
\mathrm{TL}_{\mathrm{n}}=\mathrm{S}_{\mathrm{n}} / \mathrm{S} *(\mathrm{TL}+5.20)-5.20
$$

The growth in length of $A$. bifasciatus reaches its maximum value $24.6 \mathrm{~cm}(43.85 \%)$ by the end of the second year of life, after that gradual decrease in the annual increment with further increase in age was observed (Figure 4).

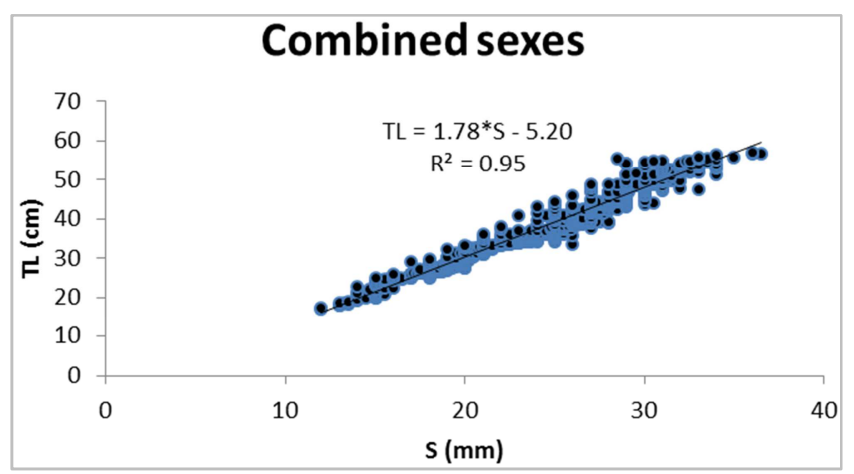

Figure 3. Total length (TL) - scale radius (S) relationships of Acanthopagrus bifasciatus from Red Sea, Egypt.

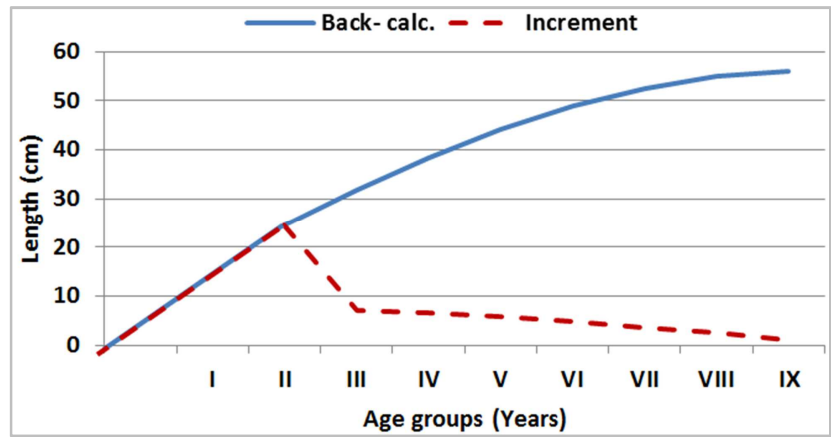

Figure 4. Back-calculated lengths $(\mathrm{cm})$ and annual increment of Acanthopagrus bifasciatus, from Red Sea, Egypt.

\subsection{Length-weight Relationship}

Males varied in total length from 17 to $56 \mathrm{~cm}$ and in weight from 95 to $3425 \mathrm{~g}$, while females ranged between 18 and $57 \mathrm{~cm}$ in total length and between 116 and $3355 \mathrm{~g}$ in weight. The estimated length-weight equations for $A$. bifasciatus fishes (Figure 5) are:

Males: W=0.0192 TL 2.989

Females: $\mathrm{W}=0.0232 \mathrm{TL}^{2.942}$

Combined sexes: $\mathrm{W}=0.0204 \mathrm{TL}^{2.974}$

The growth in weight in $A$. bifasciatus is isometric i.e. $\mathrm{b}$ is not statistically significant differs from 3 (combined sexes: $\mathrm{CI}=2.948-2.998$; males: $\mathrm{CI}=2.955-3.022$; females: $\mathrm{CI}=2.904-$ 2.985).

\subsection{Growth in Weight}

The weights corresponding to various age groups were calculated by applying the corresponding length weight relationship to the estimated lengths. The growth in weight was much slower during the second year of life for $A$. bifasciatus then increased to reach its maximum at the end of the sixth year of life then decreased with the increasing in age (Figure 6).

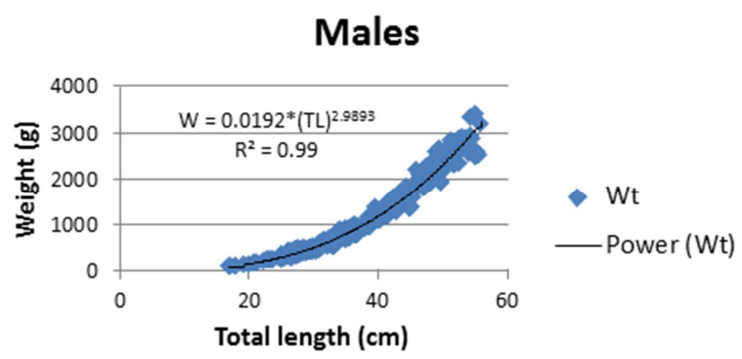

\section{Females}

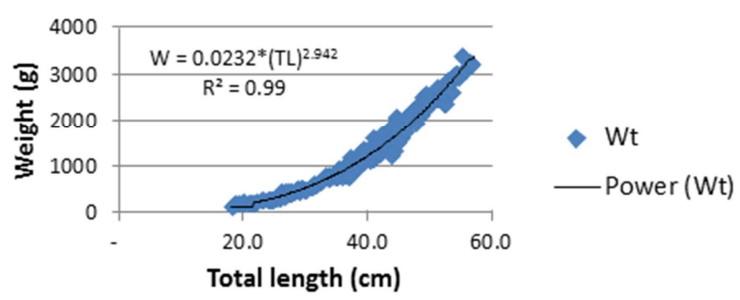

\section{Combined sexes}

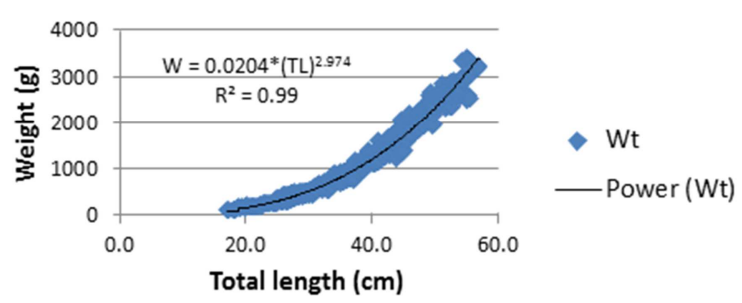

Figure 5. Length-Weight relationship of Acanthopagrus bifascitus from Red Sea, Egypt. 


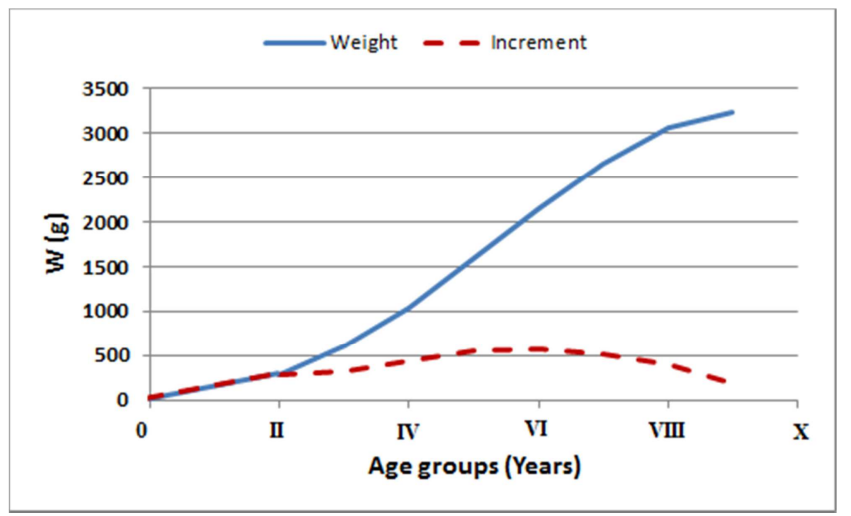

Figure 6. Calculated weights (g) and annual increment of Acanthopagrus bifasciatus from Red Sea, Egypt.

\subsection{Growth Parameters}

The constants of the von Bertalanffy growth model, estimated by Ford (1933) - Walford (1946) for A. bifasciatus are $\mathrm{L}_{\infty}=65.62 \mathrm{~cm}, \mathrm{~K}=0.21 /$ year, $\mathrm{W}_{\infty}=5170.06 \mathrm{~g}$ and $\mathrm{t}_{0}=-$ 0.101 year. Accordingly, the estimated von Bertalanffy growth in both length and weight equations were as follows:

For growth in length: $\mathrm{L}_{\mathrm{t}}=65.62\left(1-\mathrm{e}^{-0.21(\mathrm{t}+0.101)}\right)$

For growth in weight: $\mathrm{W}_{\mathrm{t}}=5170.06\left(1-\mathrm{e}^{-0.21(\mathrm{t}+0.101)}\right)^{2.974}$

\subsection{Length $\left(L_{c}\right)$ and Age $\left(T_{c}\right)$ at First Capture}

According to the resultant curve derived from catch curve, the estimated Lc was $25.31 \mathrm{~cm}$ TL for combined sexes of A. bifasciatus (Figure 7), this length was corresponding to age Tc of 2.22 year.

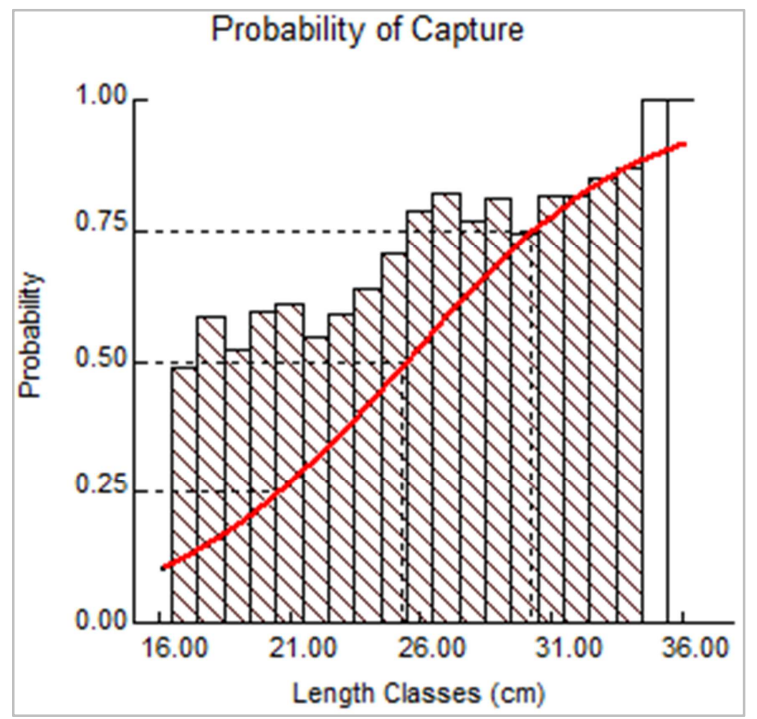

Figure 7. Probability of capture of Acanthopagrus bifasciatus from the Red Sea, Egypt.

\subsection{Length $\left(L_{r}\right)$ and Age $\left(T_{r}\right)$ at Recruitment}

The length at recruitment $\left(\mathrm{L}_{\mathrm{r}}\right)$, which refers to the smallest fish in the catch, was $17 \mathrm{~cm}$ for combined sexes of $A$. bifasciatus. The corresponding age at recruitment $\left(\mathrm{T}_{\mathrm{r}}\right)$ was 1.33 year.

\subsection{Mortality and Exploitation Rates}

The mean values of total mortality coefficient of $A$. bifasciatus estimated from Jones and Van Zalinge [20] and the length converted catch curve of [35] was 1.99/year.

The values of natural mortality coefficient of $A$. bifasciatus estimated from two different methods are 0.49 and 0.44 per year, the mean values of natural mortality was 0.46 . Accordingly, the value of fishing mortality was $\mathrm{F}=1.53$ / year and the value of exploited rate $(\mathrm{E})$ was 0.77 , that is very high and exceeds the optimum one $(\mathrm{E}=0.5)$.

\subsection{Yield per Recruit (Y/R)}

The estimated yield per recruit of $A$. bifasciatus as a function of different values of fishing mortality coefficient and age at first capture are graphically represented in Figure 8. It is found that, the current fishing mortality coefficient $(1.53 / \mathrm{y})$, age at first capture (2.22 y) and natural mortality coefficient $(0.46 / \mathrm{y})$ gives a yield of $(242.71 \mathrm{~g})$ per recruit. On the other hand, the maximum yield per recruit (250.56 g) is obtained at fishing mortality $(0.8 / \mathrm{y})$ with the same values of age at first capture and natural mortality coefficient. This means that the present level of fishing mortality is much higher than that gives the maximum yield per recruit by about $48 \%$ and the reduction of current level of fishing mortality coefficient from 1.53 to $0.8 / \mathrm{y}$ will be associated with an increase in the yield per recruit from 242.71 to $250.56 \mathrm{~g}(\approx 3 \%)$.

To investigate the variation in yield per recruit with changing of age at first capture $\left(\mathrm{T}_{\mathrm{c}}\right)$ which is related to the estimation of optimum mesh size, the yield per recruit of $A$. bifasciatus was calculated using age at first capture value equal to 3 years $(\approx \mathrm{Lm})$. The obtained results (Figure 8) indicated that the yield per recruit increases with the increase of Tc. The maximum yield per recruit at Tc equals 3 years was obtained at fishing mortality coefficient $1.7 / \mathrm{y}$ which slightly higher than the current one. This means that, the increase of age at the first capture will be associated with the increase of the maximum yield per recruit when the fishing mortality also increases.

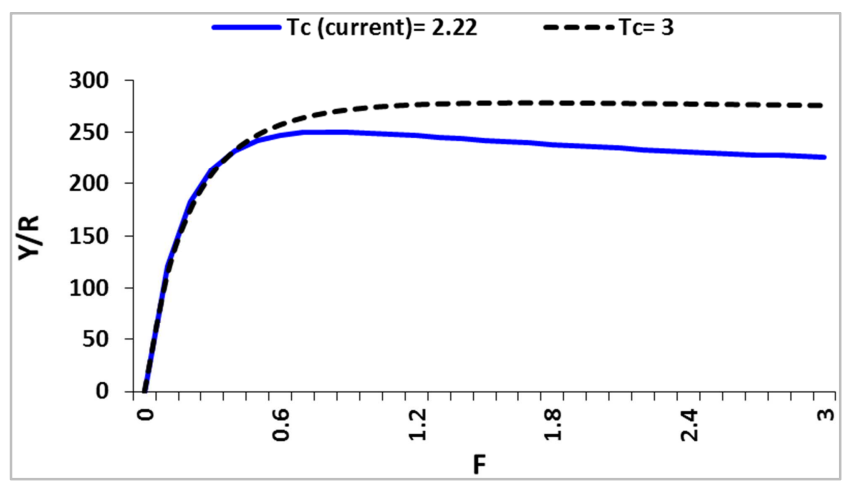

Figure 8. Yield per recruit (g) of Acanthopagrus bifasciatus from Red Sea, Egypt. 


\section{Discussion}

Sparid fishes in general and Acanthopagrus bifasciatus in particular are long lived and display a steady and slow rate of growth [34, 40]. In the present study, the longevity of $A$. bifasciatus is estimated to be 9 years and age group three was the most frequent one forming up to $26.61 \%$ of the total catch. This means that, A. bifasciatus of the Egyptian Red Sea become fully recruited to the artisanal fishery at an age of three year indicating the high fishing pressure on this species. The previous studies dealing with the age determination of the same species is those of El-Sayed and Abdel-Bary [8], who recorded 14 years in Qatar and Grandcourt et al. [14] who recorded 21 years in Emirate Abu Dhabi. It seems that there is an over estimation for age that obtained by both authors that may be due to considering the false rings and spawning rings as annual ones.

The length-weight relationship is a very useful tool in the biological study of fishes and their stock assessment. It is usually easier to measure length than weight, and then weight can be predicted later by using length-weight relationship. Furthermore, standing crop biomass can be estimated and seasonal variations in fish growth can be tracked in this way. The length-weight also helps in predicting the condition, reproductive history and life history of fish species and in morphological comparison of species and populations [2, 29].

In the present study, the growth in weight of $A$. bifasciatus relative to length was best described by the power function equation and found to be isometric growth. The associated constants of the power function equation are important basic input parameters in fisheries management programs. The analysis of length-weight relationships of $A$. bifasciatus were given by other authors showed some differences in "a" and " $b$ " values (Table 1). Such difference can be caused by one of the following factors such as salinity, temperature, food and stage of maturity $[37,6]$.

Table 1. The values of "a"and b"constants of length-weight relationship of Acanthopagrus bifasciatus of the present study compared to those from previous studies.

\begin{tabular}{llll}
\hline Author & a & b & Region \\
\hline Samual \& Mathews [40] & 0.0176 & 3.000 & Kuwait \\
El-Sayed and Abdel-Bary [8] & 0.0170 & 3.016 & Qatar \\
Present Study & 0.0204 & 2.974 & Egyptian Red Sea \\
\hline
\end{tabular}

The growth study of the present work displayed that $A$. bifasciatus attained their highest growth rate in length during the second year of life then this increment sharply decreased by the end of the second year. Similar trends in length increment have been recorded for all previous studied fish species [e.g. 9, 33, 19, 31, 32, 46].

In the present study, the growth in weight of $A$. bifasciatus was much slower in the second year of life and annual increment in weight increases with further increase in age until reaches its maximum value at age group (VI), after which a gradual decrease in annual increment was observed. This means that $A$. bifasciatus should be protected until reach the six year of life.

The mathematical description of growth is of a great importance in the field of fisheries management and fish stock assessment. The obtained growth parameters $\left(\mathrm{L}_{\infty}, \mathrm{k}\right.$ and $\mathrm{t}_{0}$ ) are the basic input data into various models used for managing and accessing the status of the exploited fish stocks. Besides, the mathematical descriptions of the growth facilitate the comparison between growth of fishes belonging to different species or to the same species at different times and different localities. Several models have been developed for the mathematical description of growth, the von Bertalanffy growth model is the most widely used [26].

The obtained growth parameters are compared with the previous available ones (Table 2). In the present study, population parameters $\left(\mathrm{L}_{\infty}, \mathrm{k} \& \mathrm{t}_{0}\right)$ of $A$. bifasciatus from the Egyptian Red Sea have different values than other localities. This difference may be due to the difference in the ecological parameters or the maximum observed lengths in the catch or the methods used in calculations in the different localities.

Table 2. Von Bertalanffy growth parameters $\left(L_{\infty}, k\right.$ and $\left.t_{0}\right)$ of Acanthopagrus bifasciatus of the present study and those of previous studies.

\begin{tabular}{|c|c|c|c|c|c|}
\hline Author & $\mathbf{L}$ & $\mathbf{L}_{\infty}(\mathbf{c m})$ & $\mathbf{k}(/ \mathbf{y})$ & $t_{0}(y)$ & Locality \\
\hline Samuel \& Mathews [40] & TL & 34.90 & 0.19 & -2.24 & Kuwait \\
\hline El-Sayed and Abdel-Bary [8] & $\mathrm{TL}$ & 47.12 & 0.14 & -1.69 & Qatar \\
\hline Grandcourt et al. [14] & FL & 32.50 & 0.23 & -2.22 & Emirate Abu Dhabi \\
\hline Present study & $\mathrm{TL}$ & 65.62 & 0.21 & -0.101 & Egyptian Red Sea \\
\hline
\end{tabular}

In the present study, the length at recruitment $\left(\mathrm{L}_{\mathrm{r}}\right)$ represented by the smallest length in the catch was $17 \mathrm{~cm}$ for A. bifasciatus. This small length indicating overfishing where they are caught before they grow large enough to contribute substantially to the stock biomass. Additionally, the estimated length at first capture $\left(\mathrm{L}_{\mathrm{c}}\right)$ was $25.31 \mathrm{~cm}$ and it was found to be less than the estimated length at first sexual maturity $\left(\mathrm{L}_{\mathrm{m}}=35.8 \mathrm{~cm}\right)$ [7] which was further evidence of overfishing that prevent them from spawning at least once before being fished.

The determination of mortality is essential as it considered one of the basic input parameters for population dynamics models used in fishery analyses and management. If we consider population growth to be a positive aspect of dynamics of fish population, then mortality can be seen as a negative counterpart [43]. A review of 10 species of Family 
Sparidae from the Mediterranean and Northwest Atlantic shows natural mortality rates to range from 0.19 to 0.66 with a mean of 0.36 [10]. In the present study, the mean estimated value of natural mortality coefficient was 0.46 but Grandcourt et al. [13, 14] reported natural mortality coefficient 0.669 and 0.22 , respectively. The same species may have different natural mortality rates in different areas depending on the density of predators and competitors, whose abundance is influenced by fishing activities [43]. Furthermore, the value of fishing mortality coefficient ( $\mathrm{F}$ $=1.53$ /y) was very high value compared with fishing mortality which reported by Grandcourt et al. [13, 14]. This reflecting an overfishing condition for A. bifasciatus stock in the Egyptian Red Sea. The exploitation rate is very important to evaluate the state of stock, which determines unexploited and overexploited stocks. The value of exploitation rate for A. bifasciatus was 0.77 and this value is higher than the optimum level of exploitation given by [16]. He mentioned that the optimum exploitation rate for any exploited fish stock is about 0.5 at $\mathrm{F}=\mathrm{M}$. So, this value indicating that $A$. bifasciatus stock is overexploited.

Without significant analysis of such data for the Red Sea, fisheries were weakly and irregularly postulated by the available miscellaneous studies. In the present study, the rate of exploitation was found to be relatively high with high total mortality for A. bifasciatus. Such result was similar with that found for all commercial fish species in the Egyptian Red Sea, this reflecting the urgent need for implementing a management plan of their rational exploitation (Mehanna [27], for lizardfish; Ahmed [1], for scarid species; Mohammad [33] for Carangoides bajad and Caranx melampygus and Mehanna et al. [30], for Lethrinid species).

Stock assessment is the part of fisheries science that studies the status of fish stock as well as the possible outcomes of different management alternatives. It tells us if the abundance of a stock is below or above a given target point and by doing so let us know whether the stock is overexploited or not. It also tells us if a catch level will maintain or change the abundance of the stock [5].

For fisheries management purposes, it is important to be able to determine changes in the $\mathrm{Y} / \mathrm{R}$ for different values of $\mathrm{F}$, but absolute values of $\mathrm{Y} / \mathrm{R}$ expressed in grams per recruit are not important for this purpose. Relative yield per recruit model for Beverton and Holt [4] can provide the best information needed for management. This model has the great advantage of requiring fewer parameters; it is especially suitable for assessing the effect of mesh size regulations [42].

In the present study, from fisheries management point of view, the estimated yield per recruit (Y/R) refers to fishing effort must be controlled and decreased for A. bifasciatus. Such result was similar with that found in all previous studies in recent 30 years in the Egyptian Red Sea.

\section{Conclusion and Recommendations}

The present results revealed that the stock of Acanthopagrus bifasciatus in the Egyptian Red Sea appears to be overexploited. Thus a fishing mortality reduction is necessary in order to avoid future loss in stock productivity and landings. So, it is recommended that: 1) Fishing effort must be controlled and decreased where the available assessment suggests a target reference point not less than $50 \%$ decreasing in fishing effort to maintain their spawning biomass; 2) Improving the fisheries data recording system, and catch- effort data collection; 3) Improving fishing pattern of the artisanal fisheries to safe the small and young fishes and 4) Revision of fisheries laws and applies strict punishment towards illegal fishers.

\section{References}

[1] Ahmed, Y. A. Population Dynamics and Stock Assessment of the most important species of Family Scaridae (parrot) in Hurghada, Red Sea. MSc. Thesis, Fishery and Aquaculture Technology, Faculty of Science, Port Said University (2015).

[2] Arslan, M.; Yildirim, A. and Bektas, S. Length-weight relationship of brown trout, Salmo trutta L., inhabiting Kan Stream, Coruh Basin, North-Eastern Turkey. Turk. J. Fish. Aqua. Sci., 4: 45-48 (2004).

[3] Beverton, R. J. H. and Holt, S. J. On the dynamics of exploited fish population. U.K. Fish. Invest. Minist. Agr. Fish Food, 19: 533 (1957).

[4] Beverton, R. J. H. and Holt, S. J. Manual of methods for fish stock assessment. Part 2. Tables of yield functions. FAO Fish. Tech. Pap., (38) Rev. 1: 67 p (1966).

[5] Bonfil, R. The purpose of stock assessment and the objectives of fisheries management. FAO Fish. Tech. Pap., No. 474, 6-14 (2005).

[6] Cherif, M.; Zarrad, R.; Gharbi, H.; Missaoui, H. and Jarboui, O. Some biological parameters of the red mullet, Mullus barbatus L., 1758, from the Gulf of Tunis. Acta Adriatica, 48 (2): 131-144 (2007).

[7] El-Mahdy, M. S. Biological studies, population dynamics and stock assessment of Acanthopagrus bifasciatus from the Red Sea, Egypt. Ph.D. Thesis, Fac. Sci. Assiut University, 155 pp. (2018).

[8] El-Sayed, A. M. and Abdel-Bary, K. Population biology of sparid fishes in Qatari waters. 2. Age, growth and mortality of black-banded bream, Mylio bifasciatus (Forsskal). Qatar Univ. Sci. J., 13 (2): 348-352 (1993).

[9] El-Serafy, S. S.; El-Gammal, F. I.; Mehanna, S. F.; AbdelHamid, N. H. and Farrag, E. F. Age, Growth and Reproduction of the Tub Gurnard, Chelidonichthys lucerna (Linnaeus, 1758) from the Egyptian Mediterranean waters off, Alexandria. International Journal of Fisheries and Aquatic Sciences 4 (1): 13-20 (2015).

[10] Erzini, K.; Bentes, L.; Coelho, R.; Correia, C.; Lino, P.; Monteiro, P.; Ribeiro, J. and Goncalves, J. M. S. Fisheries biology and assessment of demersal species (Sparidae) from the south of Portugal. UE-DG XIV 98/082. Final Report. pp 1263 (2001).

[11] Everhart, W. H.; Eipper, A. W. and Youngs, W. D. Principles of fishery science. Cornell University Press, London, 288 pp. (1975). 
[12] Ford, E. An account of the herring investigations conducted at Plymouth during the years from 1924 to1933. J. Mar. Biol. Ass. U.K., 19: 305-384 (1933).

[13] Grandcourt, E. M.; Al Abdessalaam, T. Z.; Francis, F.; Al Shamsi, A.; Al Ali, K. and Ali, S. Al. Biological reference points, resource status and management options for the key demersal species of Abu Dhabi Emirate. Fish Landings and Population Dynamics Project (Project no. 02-23-0001). Marine Environmental Research Center. ERWDA. 40 p. (2004).

[14] Grandcourt, E. M.; Francis, F.; Al Shamsi, A.; Al Ali, K. and Ali, S. Al. Stock assessment and biology of key species in the demersal fisheries of the Emirate of Abu Dhabi. Fish Landings and Population Dynamics Project (Project no. 0223-0001). Marine Environmental Research Center. ERWDA. 75 p. (2003).

[15] Gulland, J. A. Manual of methods for fish stock assessment. Part (1). Fish population analysis. FAO Man. Fish. Sci. 4: 154p. (1969).

[16] Gulland, J. A. The fish resources of the Ocean. West Byfleet, Surrey, Fishing News, Ltd., FAO, 255 p. (1971).

[17] Gulland, J. A. Fish stock assessment: a manual of basic methods. FAO/Wiley Series on Food and Agriculture, 1: 223 p. (1983).

[18] Gumanao, G. S.; Saceda-Cardoza, M. M.; Mueller, B. and Bos, A. R. Length-weight and length-length relationships of Indo-Pacific fish species (Teleostei) from the Davao Gulf, Philippines. J. Appl. Ichthyol. 32 (2016), 377-385 (2016).

[19] Hammam, E. M. Biological studies, stock assessment and fisheries management of some species of family Mullidae from the Mediterranean Sea at Alexandria. Ph.D. Thesis, Fac. Sci. Assiut University, 176 pp. (2017).

[20] Hile, R. Age and growth of the Cisco leucichthys artedi (Le Sueur) in the lakes of the north Eastern highlands, Wisconsim. Bull. U. S. Bur. Fish., 19: 211-3 17 (1936).

[21] Jones, R and Van Zalinge, N. P. Estimates of mortality rate and population size for shrimp in Kuwait waters. Kuwait Bull. Mar. Sci., 2: 273-288 (1981).

[22] Lassen, H. and Medley, P. Virtual Population Analysis. A Practical Manual for Stock Assessment. FAO Fisheries Technical Paper No. 400. FAO, Rome. 129 pp. (2001).

[23] Le Cren, E. D. The length-weight relationship and seasonal cycle in gonad weight and condition in the perch Perca fluviatilis. J. Anim. Ecol., 20: 201-219 (1951).

[24] Lieske, E. and Myers, R. Collins Pocket Guide. Coral reef fishes. Indo-Pacific \& Caribbean including the Red Sea. Haper Collins Publishers, 400 p. (1994).

[25] Makkey, A. F. Population dynamics and stock assessment of Lethrinus lentjan and Lethrinus microdon (family: Lethrinidae) in the Egyptian coast of Red Sea. Ph. D. Thesis, Fac. Sci., Al-Azhar University (Cairo branch), 200 pp. (2017).

[26] Mehanna, S. F. A study of the Biology and Population Dynamics of Lethrinus mahsena (Forsskal, 1775) in the Gulf of Suez. Ph. D. Thesis, Zagazig University, Egypt (1996).

[27] Mehanna, S. F. Population dynamical parameters of the Atlanic lizardfish (Synodus saurus) from the Mediterranean
Waters of Egypt. International Congress On "Estuaries \& Coastal Protected Areas", ECPA 2014, 04 - 06 November 2014, Izmir-Turkey (2014).

[28] Mehanna, S. F. Population dynamics of two Lessepsian migrant goatfish species; Upeneus pori and Upeneus moluccensis from the southeastern Mediterranean, Port Said region, Egypt. First Euro-Mediterranean Conference for Environmental Integration, 22-25 November, 2017, Sousse, Tunisia (2017).

[29] Mehanna, S. F. and Al-Mammry, J. Length-weight relationship of 19 pelagic and demersal fish species from the sea of Oman. $4^{\text {th }}$ International conference on Fisheries and Aquaculture researches, Cairo, 3-6 October, (2012).

[30] Mehanna, S. F.; El-Gammal, F. I.; Zaahkouk, S. A.; Khalaf-Allah, H. M. M. and Makkey, A. F. Population dynamics of the small tooth emperor, Lethrinus microdon (Valenciennes, 1830) from the Egyptian Red Sea. International Journal of Fisheries and Aquatic Studies 2017; 5 (2): 158-163 (2017a).

[31] Mehanna, S. F.; Osman, A. M.; Farrag, M. M. and Ahmed, Y. A. Age and growth of three common species of goatfish exploited by artisanal fishery in Hurghada fishing area, Egypt. Journal of Applied Ichthyology (2017b).

[32] Mehanna, S. F.; Soliman, F. M.; Soliman, H. A. and Baker, T. S. Age, growth and length-weight relationship of Lutjanus quinqelineatus (Boch, 1790) and Lutjanus ehrenbergii (Petere, 1869) from the Red Sea, Egypt. Al-Azhar University, Assiut Branch annual conference, Hurghada (2017c).

[33] Mohammad, A. S. Biological studies, stock assessment and fisheries management of Carangoides bajad (Forsskal, 1775) and Caranx melampygus (Cuvier, 1833) from the Red Sea, Egypt. Ph. D. Thesis, Zoology Department, Faculty of Science, Assiut University (2016).

[34] Morgan, G. R. Assessment of sheim, Acanthopagrus latus in Kuwait waters. Proc., 1984 Shrimp and Fin Fisheries Management Workshop. Mathews, C. P. (ed). Kuwait Institute for Scientific Research, 1862: 116-124 (1985).

[35] Pauly, D. On the interrelationships between natural mortality, growth parameters and mean environmental temperature in 175 fish stocks. J. Cons. CIEM, 39 (3): 175-192 (1980).

[36] Pauly, D. Length-converted catch curves. A powerful tool for fisheries research in the tropics. Part I. ICLARM Fishbase, 1 (2): 9- 13 (1983).

[37] Pauly, D. Fish population dynamics in tropical waters: a manual for use with programmable calculators. ICLARM Stud. Rev., 8: 325 p. (1984).

[38] Pope, E. C.; Hays, G. C.; Thys, T. M.; Doyle, T. K.; Sims, D. W.; Queiroz, N.; Hobson, V. J.; Kubicek, L. and Houghton, J. D. R. The biology and ecology of the ocean sunfish Mola mola: a review of current knowledge and future research perspectives. Reviews of Fish Biology and Fisheries 20: 471487 (2010).

[39] Rikhter, V. A. and Efanov, V. N. On one the approaches to estimation of natural mortality of fish population. ICNAF Res. Doc. 76/VI/8: 12p. (1976).

[40] Samuel, M. and Mathews, C. P. Growth and mortality of four Acanthopagrus species. Kuwait Bul. Sci., 9: 159-171 (1987). 
[41] Sommer, C.; Schneider, W. and Poutiers, J. M. FAO Species Identification Field Guide for Fishery Purposes the Living Marine Resources of Somalia. FAO, Rome, Pages: 376. (1996).

[42] Sparre, P. and Venema, S. Introduction to tropical fish stock assessment Part 1 Mannual FAO Fish. Tech. Pap., 306/1, Rev., 1: 376 p. (1992).

[43] Sparre, P. and Venema, S. Introduction to Tropical Fish Stock Assessment-Part 1: Manual. FAO Fisheries Technical Paper 306/1 Rev. 2. (1998).

[44] Tracey, S. R.; Lyle, J. M. and Haddom, M. Reproductive biology and per-recruit analysis of striped trumpeter (Latis lineta) from Tasmania, Australia: Implications for management. Fisheries Research, 84: 358-367 (2006).

[45] Walford, L. A.: A new graphic method of describing the growth of animals. Biol. Bull. Mar. Biol., 90 (2): 141-147 (1946).

[46] Zaahkouk, S. A.; Khalaf-Allah, H. M.; Mehanna, S. F.; ElGammal F. I. and Makkey, A. F.. Studies on age, growth, and mortality rates for management of the redspot emperor, Lethrinus lentjan (Lacepède, 1802) in the Egyptian sector of Red Sea. Egyptian Journal of Aquatic Biology \& Fisheries, 21 (1): 63-72 (2017). 